Pamiętnik Literacki 2019, 4, s. 109-116

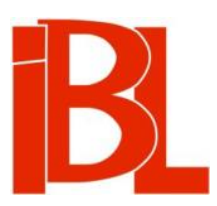

\title{
Podstawowe wartości uniwersytetu
}

Jerzy Marian Brzeziński 
Pamiętnik Literacki CX, 2019, z. 4, PL ISSN 0031-0514

DOI: $10.18318 / \mathrm{pl} .2019 .4 .7$

JERZY MARIAN BRZEZIŃSKI Uniwersytet im. Adama Mickiewicza w Poznaniu, Wydział Psychologii i Kognitywistyki

\section{PODSTAWOWE WARTOŚCI UNIWERSYTETU}

Uniwersytet ma za sobą długą historię trwania. Mądrość wielu pokoleń ludzi uniwersytetu budowała jego społeczny prestiż i społeczną użyteczność. I trudno dziś wyobrazić sobie społeczeństwo bez uniwersytetu.

Jednakże ta „użyteczność” nie może być pojmowana tak wąsko, jak chciałoby otoczenie korporacyjno-przedsiębiorcze. Uniwersytet nie jest przedsiębiorstwem i nie hołduje specyficznym wartościom składającym się na tzw. kulturę korporacyjną, która stanowi swoisty negatyw typowej dla klasycznego Humboldtowskiego uniwersytetu „kultury wspólnotowej” ${ }^{1}$. W owym, narzuconym przez otoczenie biznesowe, kanonie antywartości akademickich Piotr Sztompka widzi główne zagrożenie dla współczesnych uniwersytetów:

w naszych czasach, w których głównym tematem przenikającym całe życie społeczne jest produkcja i konsumpcja, fabrykowanie i kupowanie („ekonomia, głupcze!”), teren uniwersytetu zaatakowała, niczym wirus, diametralnie przeciwna jego naturze kultura korporacyjna, której właściwe miejsce to firmy, przedsiębiorstwa, banki, urzędy administracyjne. W uniwersytecie pojawiły się obok siebie dwie kultury: wspólnotowa i korporacyjna, całkowicie ze sobą niezgodne. Ten dysonans to w moim przekonaniu źródło kryzysu instytucji uniwersytetu. Co gorsze, w rękach oszołomionych fetyszem nowoczesności administratorów, nadsłuchujących chętnie bajek pseudouczonych o „uniwersytecie posttradycyjnym”, doszło do erozji modelu tradycyjnego, tego spontanicznie przez wieki wytworzonego ładu wspólnotowego, akademickiego Gemeinschaft i do apoteozy narzuconego odgórnie ładu korporacyjnego, modelu akademickiego przedsiębiorstwa. Wahadło odchyliło się w jedną stronę znacznie za daleko²

Nie jest zatem (nie powinien być) uniwersytet pozostająca na usługi korporacji szkołą zawodową, która przygotowuje wąsko wyspecjalizowanych fachowców, bezpośrednio wchodzących do sfery objętej nadzorem biznesowym.

Wreszcie uniwersytet, w szczególności, nie realizuje zadań formułowanych dlań przez polityków aktualnie rządzącej partii. Nie jest jej własnością. Chociaż, jak zauważył Karl Jaspers, wytwory umysłów polityków czy ich zachowania mogą być przedmiotem badań naukowych prowadzonych na uniwersytecie. Sam zaś uniwersytet, $z$ natury swej, działa autonomicznie.

Polityka istnieje na uniwersytecie nie jako walka, ale wyłącznie jako przedmiot badań. Gdy na uniwersytetach toczy się walka polityczna, szkodę ponosi idea uniwersytetu. Fakt, że byt i zewnętrzny kształt szkoły wyższej zależą od politycznych rozstrzygnięć, spoczywając na fundamencie niezawodnej

1 P. Sztom p ka, Uniwersytet wspótczesny; zderzenie dwóch kultur. „Nauka” 2014, nr 1.

2 Ibidem, s. 8-9. 
woli państwa, oznacza, że w obrębie takiej szkoły - a zatem w przestrzeni wydzielonej przez państwo realizuje się nie praktyczna walka, nie polityczna propaganda, ale jedynie pierwotne poszukiwanie prawdy.

To oznacza wymóg bezwzględnej wolności nauczania. Państwo gwarantuje w tym punkcie korporacji prawo, aby nauczyciele, bez wpływu ze strony politycznej woli partyjnej lub przymusu światopoglądowego, podjęli, kierując się względami czysto merytorycznymi, próbę badania i uczenia prawdy³.

Upolitycznianie uniwersytetów zawsze prowadziło do ograniczania ich autonomii i - w konsekwencji - do obniżenia poziomu badań naukowych i poziomu kształcenia. Towarzyszyło temu - co w takich przypadkach nieuniknione - obniżenie standardów etycznych w pracy badawczej i nauczycielskiej. Szczególnie dotkliwie odczuły to uniwersytety w krajach o ustrojach totalitarnych. Pamiętajmy jednak, że te zagrożenia nie zostały od uniwersytetu raz na zawsze oddalone. Musimy być, właśnie jako profesorowie, wrażliwi na wszelkie przejawy łamania demokracji i odchodzenia od ideałów uniwersytetu.

Moim zdaniem, w ostatnim czasie jeszcze jedna instytucja (a ściślej mówiąc: wypowiadający się w jej imieniu funkcjonariusze, jak też politycy) chciałaby decydować o tym, co wolno, czego zaś nie wolno czynić (badać, nauczać) na polskich uniwersytetach. Tą instytucją jest Kościół katolicki. Dwa niepokojące przykłady.

Pierwszy. Redaktor naczelny opiniotwórczego w kręgach katolickich częstochowskiego tygodnika „Niedziela”, ks. Ireneusz Skubiś, odniósł się krytycznie do wypowiedzi redaktora naczelnego miesięcznika internetowego „Liberté!” Leszka Jażdżewskiego, która poprzedzała wykład przewodniczącego Rady Europejskiej Donalda Tuska wygłoszony przez niego na Uniwersytecie Warszawskim 3 maja tego roku ${ }^{4}$. Skubiś zaapelował o „krytyczne” przyjrzenie się temu, co dzieje się na UW i innych polskich uniwersytetach:

Stało się to na Uniwersytecie Warszawskim. Wiadomo, co o roli uniwersytetu mówił Jan Paweł II, na którego wypowiedzi tak często się powołujemy. Co z tym zrobią UW i inne uniwersytety w Polsce? Co z tym zrobi min. Jarosław Gowin? Myślę, że słowne oświadczenie to jednak za mało. Trzeba merytorycznie zwrócić uwagę na to, co się dzieje na uniwersytetach ${ }^{5}$.

Drugi. Pewna posłanka na Sejm RP zapytała ministra Jarosława Gowina, jak długo jeszcze będzie tolerował w publicznych szkołach wyższych kształcenie na kierunkach gender studies. I - całkiem poważnie - zapytała też (w interpelacji poselskiej) czy rozważa on likwidację tego kierunku studiów. Wspomagał ja - oczywiście „naukowo” - inny polityk o tych samych przekonaniach, który uważa, że te studia to „ideologia” odwołująca się do „tzw. teorii marksistowsko-leninowskiej”. Trudno racjonalnie $z$ takim poglądem dyskutować.

Uniwersytet w państwie świeckim (a takim, jeszcze, jest Polska) - nie zaś wyznaniowym - musi być wolny od jakichkolwiek nacisków: i tych ekonomicznych, i tych politycznych, i tych religijnych. Osobiście jest mi bardzo bliskie stanowisko, które zajął w tej kwestii historyk idei Jerzy Jedlicki (2010): „zawodowym obowiąz-

3 K. Jas pers, Idea uniwersytetu. Przeł. W. Kun i cki. Warszawa 2017, s. 175.

4 Zwróciłem uwagę na tę wypowiedź dzięki lekturze tekstu T. Sła w ka Rozum, furia i wiara („Tygodnik Powszechny” 2019, nr 31).

5 I. Skubiś, Co się stało na Uniwersytecie Warszawskim 3 maja 2019? „Niedziela” 2019, nr 20, s. 37. 
kiem pracownika naukowego jest nieposłuszeństwo w myśleniu”. I dodawał, przytaczając słowa Stanisława Ossowskiego: „Pod tym względem nie wolno mu być posłusznym ani synodowi, ani komitetowi, ani ministrowi, ani cesarzowi, ani Panu Bogu"6.

Powiedzmy wyraźnie: dziś nam, jak nigdy dotychczas, potrzebny jest „uniwersytet otwarty", występujący przeciwko ksenofobii, dogmatyzmom i nietolerancji, uniwersytet pluralistyczny, rozumiejący i empatyczny. Nie może to być uniwersytet z wizji wielkiego filozofa Martina Heideggera, która zawarł on w słynnej, haniebnej mowie rektorskiej, zatytułowanej Samoutwierdzenie się niemieckiego uniwersytetu, wygłoszonej po objęciu przez niego rektoratu uniwersytetu we Fryburgu badeńskim 27 III $1933^{7}$.

Uniwersytet musi, właśnie w imię swojej wielowiekowej misji, podjąc zadania formacyjne - nie mniej ważne od zdobywania wiedzy naukowej i rozwijania umiejętności. Jedno z tych zadań wiąże się $\mathrm{z}$ kształtowaniem postawy pluralizmu - zarówno w badaniach naukowych, jak i w życiu codziennym.

Różnorodność zatem jako wartość dookreślająca ideę uniwersytetu przyjmuje dwojaki sens. Wedle pierwszego oznacza równoważność wielu dróg prowadzących do odkrycia naukowego. Mówiąc inaczej, oznacza poszanowanie pluralizmu teoretycznego i metodologicznego w poszukiwaniach badawczych. Tylko w warunkach dialogu pomiędzy osobami o różnych preferencjach światopoglądowych, teoretycznych i metodologicznych możliwe jest kształtowanie „osobowości badawczej" 8 młodego człowieka. Jak pokazały liczne studia naukowe przeprowadzone przez psychologów społecznych i socjologów ${ }^{9}$, praca badawcza w zespołach zróżnicowanych etnicznie jest bardziej efektywna. Pozytywny klimat imigracyjny jej sprzyja. Niestety, wyniki badań zespołu Bilewicza dotyczące sytuacji studentów i doktorantów obcokrajowców na UW nie napawają optymizmem: „Na tysiąc obcokrajowców studiujących na Uniwersytecie Warszawskim aż 59 procent doświadczyło jakiejś formy dyskryminacji” ${ }^{10}$. Wniosek: wiele pracy formacyjnej przed nami!

$Z$ kolei, zgodnie $z$ drugim sensem, różnorodność to wielość orientacji światopoglądowych, wielość przekonań politycznych, wielokulturowość. Uniwersytet uczy (powinien uczyć!) postawy tolerancji i dezaprobaty dla najmniejszych nawet przejawów etnocentryzmu, obskurantyzmu, antysemityzmu czy fundamentalizmu re-

J. Jedlicki, Kołakowski: historia i odpowiedzialność - $w$ pierwsza rocznice śmierci. „Gazeta Wyborcza” 2010, nr 165, z 17-18 VII, s. 21. Cytat z S. O s s ow s ki e go pochodzi z jego tekstu: Taktyka i kultura („Przegląd Kulturalny” 1956, nr 13).

7 M. He i d e g g e r, Samoutwierdzenie się niemieckiego uniwersytetu. Przeł. J. G a r e w i c z. „Aletheia" nr 1 (4) (1990): Heidegger dzisiaj. Red. P. Marciszuk, C. Wodziński.

8 Termin zapożyczony od L. N o w a ka (O osobowości badawczej i konieczności szkót w nauce. W zb.: Krytyka, inspiracje, otwarcia w pedagogice. Red. E. Rodzi e wi cz. Gdańsk 1995).

9 Zob. M. Bilew i c z, Uniwersytet różnorodny politycznie i kulturowo, czyli jak wspią́ się na naukowe szczyty? Referat wygłoszony na konferencji: Uniwersytet XXI wieku: od Humboldta do Uniwersytetu 4.0, zorganizowanej 3-4 IV 2019 na Uniwersytecie im. Adama Mickiewicza w Poznaniu. Zob. też omówienie tego referatu: E. K o n a r z e w s k a - M i c h a la k, Uniwersytety otwarte na imigrantów osiagają więcej. Na stronie: https://uniwersyteckie.pl/sto-lat-uam/uniwersytety-otwarte-naimigrantow-osiagaja-wiecej (data dostępu: 10 VIII 2019). 
ligijnego. Powinien działać ponad jakimikolwiek granicami. Najzwięźlej zostało to wyrażone w „Wielkiej Karcie Uniwersytetów Europejskich” (Magna Charta Universitatum) z r. 1988:

Uniwersytet - jako instytucja odpowiedzialna za utrwalanie europejskiej tradycji humanistycznej stale dba o tworzenie wiedzy uniwersalnej, a realizując swoje powołanie, przenika granice geograficzne i polityczne oraz potwierdza konieczność poznawania i wzajemnego oddziaływania na siebie różnych kultur ${ }^{11}$.

Jest oczywiste, że na uniwersytecie prowadzi się badania naukowe. I to te o charakterze podstawowym. A to ważne zadanie - wszak dążenie do prawdy stanowi jeden $z$ najbardziej fundamentalnych celów uniwersytetu. Ale uniwersytet nie jest (nie powinien być) wyłącznie instytucją skupioną na osiągnięciach naukowych. Nie zajmuje się jedynie „kopiowaniem” zadan przypisanych instytucjom badawczym (np. Instytutom PAN).

Jego jeszcze dwa bardzo ważne obowiązki - obok wymienionego już wzbogacania wiedzy naukowej czy, jak by powiedział Kazimierz Twardowski, „odkrywania coraz to nowych prawd i prawdopodobieństw naukowych" 12 - to:

1. Dostarczanie studentom i doktorantom ciagle aktualizowanej wiedzy naukowej i kształtowanie, opartych na tej wiedzy, umiejętności. Ta ważna rola uniwersytetu związana jest $\mathrm{z}$ przygotowywaniem specjalistów niezbędnych do prawidłowego obsługiwania sfery praktyki społecznej.

2. Wypełnianie misji formacyjnej. Uniwersytet musi - i podkreślmy to - wychowywać, musi kształtować nowe elity dla wolnego, tolerancyjnego, demokratycznego i kreatywnego społeczeństwa.

Aby zrealizować skutecznie tę drugą misję, niezbędne jest przywrócenie zachwianych proporcji między naukami „twardymi” (science) a „miękkimi” (humanities). Te pierwsze sa - także w Polsce - zdecydowanie faworyzowane (również w funkcjonujących od lat dziewięćdziesiątych ubiegłego wieku systemach ewaluacji uniwersytetów i ich finansowania). Jednak mimo łożenia relatywnie dużych środków finansowych (ze skromnego - w stosunku do większości krajów UE, że nie wspomnę o światowych gigantach - koszyka) Nagroda Nobla omija polskie wydziały fizyki, chemii czy medycyny. Zaniedbując nauki humanistyczne i społeczne, rządowi decydenci zdaja się zapominać, że to dobrze wykształceni absolwenci tych kierunków zasilą - także - szeregi nauczycieli szkolnictwa podstawowego i średniego. Od ich profesjonalizmu zależeć będzie poziom przyszłych studentów pierwszego roku - również kierunków ścisłych: technicznych, przyrodniczych i medycznych.

„Ogłada” humanistyczna niezbędna jest też dla zaangażowanych w budowanie społeczeństwa obywatelskiego elit wykształconych na wydziałach ścisłych i przyrodniczych. Powtórzę, uniwersytety nie są szkołami zawodowymi, które przygotowują absolwentów do podjęcia pracy na wysoce wyspecjalizowanych stanowiskach produkcyjnych. Narzucana z zewnątrz konieczność wąskiej specjalizacji prowadzi

11 Magna Charta Universitatum (Bolonia, 18 IX 1988). Na stronie: http://www.magna-charta.org/ resources/files/the-magna-charta/polish (data dostępu: 10 VIII 2019). 
do nieuchronnego przekształcania uniwersytetu w szkołę zawodową. To zaś grozi jak to ujął hiszpański myśliciel José Ortega y Gasset - „barbarzyństwem specjalizacji”. A swoistym „produktem” tak zredukowanego uniwersytetu są „specjaliści”:

Przedtem ludzi dzieliło się w sposób prosty, na mądrych i głupich, na mniej lub bardziej mądrych i mniej lub bardziej głupich. Ale specjalisty nie można włączyć do żadnej z tych kategorii. Nie jest człowiekiem mądrym, bo jest ignorantem, jeśli chodzi o wszystko, co nie dotyczy jego specjalności; jednak nie jest także głupcem, ponieważ jest „człowiekiem nauki” i zna bardzo dobrze swój malutki wycinek wszechświata. Trzeba więc o nim powiedzieć, że jest mądro-głupi ${ }^{13}$.

Uzupełnienie treściami humanistycznymi i społecznymi programów kształcenia jest niezbędne do prawidłowego wchodzenia absolwentów w role zawodowe. Wszak dorosłe życie nie zamyka się w ramach wyznaczonych przez instrukcję obsługi stanowiska pracy. Na niebezpieczeństwo minimalizowania przez rząd znaczenia nauk humanistycznych dla właściwego kształtowania się otwartego społeczeństwa obywatelskiego wskazała Martha Nussbaum w książce o wielce mówiącym tytule Nie dla zysku. Dlaczego demokracja potrzebuje humanistów:

edukacja powiązana $z$ tradycjami sztuk wyzwolonych uwzględnia fakt, że szkoła wyższa powinna przygotowywać studentów do dwóch różnych ról: do rozwijania kariery zawodowej, jak również do bycia obywatelem.

w angielskiej kulturze edukacyjnej - przynajmniej od czasów rządów Margaret Thatcher, a zapewne o wiele wcześniej - dokonano dewaluacji nauk humanistycznych w sposób o wiele bardziej agresywny niż gdziekolwiek indziej. Nauki te mają wykazywać swoją przydatność dla wąsko rozumianych celów komercyjnych ${ }^{14}$.

Na niebezpieczeństwo marginalizowania znaczenia nauk humanistycznych zwracają uwagę eksperci American Academy of Arts \& Sciences, którzy w r. 2013 przygotowali raport o roli nauk humanistycznych i społecznych w kształtowaniu demokratycznego społeczeństwa: The Heart of the Matter. The Humanities and Social Sciences for a Vibrant, Competitive, and Secure Nation ${ }^{15}$. Uważam, że i Polska Akademia Nauk mogłaby zdobyć się na podobny raport.

Niestety, ale także w Polsce zostały w dużym stopniu zachwiane proporcje, jeśli chodzi o realizowanie tych trzech celów uniwersytetu: prowadzenia nowatorskich badań naukowych, dostarczania studentom i doktorantom nowej wiedzy, wykonywania zadań formacyjnych.

W szczególności nie przywiązuje się dostatecznej wagi do zadań formacyjnych. Znalazły się one (jeżeli w ogóle są systematycznie, a nie tylko okazjonalnie podejmowane) na dalszym planie. Przy widocznej niewydolności szkolnictwa w tym obszarze edukacji uniwersytety nie uważają, że należy oddziaływać na osoby „dorosłe”

J. Ortega y Gasset, Bunt mas i inne pisma socjologiczne. Wstęp J. Szacki. Wybór, oprac. S. Ci ch ow ic z. Warszawa 1982, rozdz. Barbarzyństwo „specjalizacji”, s. 132 (przeł. P. Niklewicz).

14 M. C. N u s s b a u m, Nie dla zysku. Dlaczego demokracja potrzebuje humanistów. Przeł. Ł. P a włow ski. Wstęp J. Ku is z. Warszawa 2016, s. 168, 172.

15 The Heart of the Matter. The Humanities and Social Sciences for a Vibrant, Competitive, and Secure Nation. (2013). Na stronie: https://www.humanitiescommission.org/_pdf/hss_report.pdf (data dostępu: 10 VIII 2019). 
(nominalnie $-\mathrm{z}$ prawnego, ale nie $\mathrm{z}$ psychologicznego punktu widzenia). Nie do końca świadome negatywnych dla społeczeństwa długofalowych konsekwencji strusiej polityki, ministerstwo nadzorujące działalnośc uniwersytetów kieruje ich aktywność na to, za co uzyskają one prestiżowe wysokie oceny ich pracy. A te oceny powiązane sa $z$ systemem przyznawanych - w okresowo prowadzonych ewaluacjach - tzw. „punktów parametrycznych”. Te zaś otrzymuje się - przede wszystkim! - za lokowane w tzw. dobrych czasopismach naukowych artykuły oraz za monografie, granty i patenty.

Działalność dydaktyczna i formacyjna nie przekłada się na punkty. No bo jak to zrobić? Łatwiej dodawać arbitralnie przyznawane - za drukowanie w czasopismach - punkty lub takie wskaźniki, jak IF (Impact Factor) czy liczby cytowań. Nawet bardzo zaangażowana i czasochłonna praca formacyjna $z$ młodzieżą nie przynosi uczelniom punktów i nie ma żadnego wpływu na uzyskaną w ocenie parametrycznej kategorię - najlepiej: „+A” czy „A”. Mówiąc najprościej: uczelniom „nie opłaca się" realizowanie zadań formacyjnych. Nawet najlepiej - w interesie społecznym! - wykonana praca wychowawcza nie jest przez instytucje nadzorujace działalność uniwersytetów doceniana. Liczą się tylko punkty. Te zaś są pochodną wytworzonych publikacji. Dobrze wiedzą o tym i pracownicy, i doktoranci. Pamiętając o starej zasadzie: „publish or perish”, robią tylko to, co zapewni zatrudnienie czy szybki awans naukowy (naruszając przy tym - i to wcale nie tak rzadko - dobre obyczaje w nauce ${ }^{16}$ ). Same zaś uniwersytety upodabniają się do instytutów badawczych - nie zawsze najwyższej rangi naukowej. To smutne. Nasze uniwersytety przestają być tymi, o których pisał Twardowski w swoim eseju $O$ dostojeństwie uniwersytetu:

praca wy chow aw c za profesora i docenta Uniwersytetu nie jest dla niego czymś obcym i zewnętrznym, lecz zlewa się $\mathrm{z}$ jego praca n a u c zy ci el s ka, polegająca na wyrabianiu w studentach umiejętności myślenia i badania naukowego, która to praca nauczycielska ma za podstawę własną pracę badawczą nauczyciela. Tak więc w jedno się splatają trzy kierunki działania profesora i docenta Uniwersytetu, tworząc w swym połączeniu pełną istotę ich zawodu ${ }^{17}$.

Moim zdaniem, zamiast po raz setny dyskutować nad strategiami publikacyjnymi i „sprawiedliwa/niesprawiedliwą” dystrybucja punktów parametrycznych powinniśmy poważnie zastanowić się nad prymarnymi, „miękkimi”, zadaniami uniwersytetu. Porzućmy zatem poszukiwania „sprawiedliwego” (tylko z czyjego punktu widzenia?) algorytmu zamiany rezultatów pracy badawczej na punkty. Nie dajmy się wciagać w „gry liczbowe” (w takim sensie, w jakim pisze o tym David Lorge Parnas ${ }^{18}$ ).

Trafnie ują ten - moim zdaniem, podstawowy i dla kondycji uniwersytetu

J. Brze z i ń s ki, Źródła nieetycznych zachowań badaczy i nauczycieli akademickich z dziedziny nauk społecznych. W zb.: Filozof $w$ krainie umysłów. Profesorowi Andrzejowi Klawiterowi $w$ darze. Red. G. Króliczak [i in.]. Poznań 2018.

17 Twardowski, op. cit., s. [20].

18 D. L. Parn a s, Stop the Numbers Game. Counting papers slows down the rate of scientific progress. „Communications of the ACM" t. 50 (2007), nr 11. Na stronie: http://www.cosy.sbg.ac.at/ helmut/ Stuff/parnas07.pdf (data dostępu: 10 VIII 2019). 
przyszłości (nie tylko w Polsce), i dla „odbiorcy” efektów jego prac: społeczeństwa obywatelskiego - problem Tadeusz Sławek:

dzisiaj widzimy bardzo ostro, iż nie wystarczą jedynie wiedza i fachowe umiejętności, aby uczynić świat życzliwszym miejscem nie tylko dla człowieka, ale dla wszystkich istot na nim żyjących. $Z$ jednej strony wciąż jesteśmy częścią oświeceniowego projektu zakładającego nieustanne doskonalenie wiedzy jako warunku czynienia świata życzliwym, z drugiej - widzimy wyraźnie, że zadanie to wymaga czegoś, co wykracza poza ów projekt, a może nawet wręcz go „warunkuje”. Uniwersytetowi potrzebny jest więc pewien radykalizm po to, aby służąc wiedzy, celebrując ją i doskonaląc, nie uległ całkowicie jej władzy, aby nie dopuścił do tego, by tylko wiedza stała się jedynym „warunkiem” jego istnienia ${ }^{19}$.

Na podstawie analizy ważnych tekstów traktujących o misji uniwersytetu w naszej kulturze - tych klasycznych ${ }^{20}$ i tych współczesnych ${ }^{21}$ - dokonałem rekonstrukcji wymiarów przestrzeni aksjologicznej uniwersytetu. Przedstawia ją ten oto schemat:

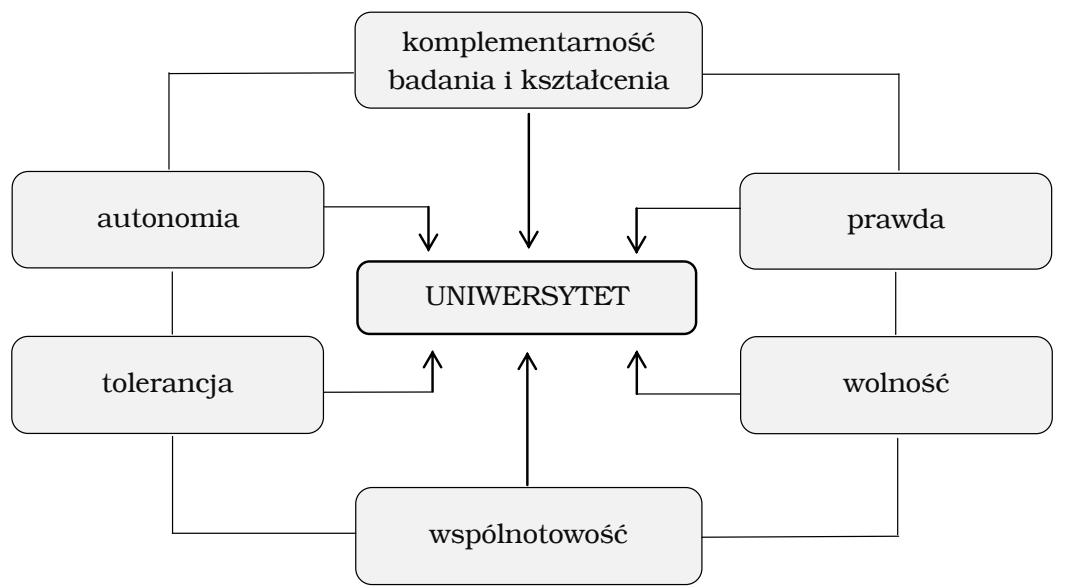

Wartości uniwersytetu

Niniejszy artykuł właśnie na tych wartościach się koncentrował.

T. Sła w e k, Uniwersytet i to, co między ludźmi. „Nauka” 2009, nr 2. Podkreśl. J. M. B.

Zob. Tward ow ski, op. cit. - J. H. New man, Idea uniwersytetu. Przeł. P. M roczkowski. Warszawa 1990. - T. Czeżow ski, Uniwersytet nowoczesny. W zb.: Tożsamość uniwersytetu. Antologia tekstów Profesorów Uniwersytetu Mikołaja Kopernika. Red. W. Win cła w s ki. Toruń 1994. - J a s pers, op. cit.

Zob. Magna Charta Universitatum. - L. Ko ł a k o w s k i, Po co uniwersytet? Referat wygłoszony na konferencji Dylematy szkolnictwa wyższego, zorganizowanej w r. 1993 przez wiedeński Institut für Wissenschaften vom Menschen w Warszawie. Przedruk w: L. Koła k ow s ki, Czy Pan Bógjest szczęśliwy i inne pytania. Kraków 2009. - Sła w e k, Uniwersytet i to, co między ludźmi. - The Heart of the Matter. The Humanities and Social Sciences for a Vibrant, Competitive, and Secure Nation. - P. Sz t o m p k a: Uniwersytet wspótczesny; zderzenie dwóch kultur; Autonomia - fundament kultury akademickiej. „Nauka” 2017, nr 3. - N u s s b a u m, op. cit. - B. Reading s, Uniwersytet $w$ ruinie. Przeł. S. S t e ck o. Warszawa 2017. 


\author{
Abstract \\ JERZY MARIAN BRZEZIŃSKI Adam Mickiewicz University in Poznań, \\ Faculty of Psychology and Cognitive Science
}

\title{
BASIC VALUES OF UNIVERSITY
}

In the article the author identifies three missions of the classic Humboldtean university: (a) research, (b) education, (c) formation. It is possible to fulfil these missions thoroughly if the canon of basic values originating from the classic vision of university (formulated by Wilhelm von Humboldt, the founder of the Humboldt University of Berlin), which defines axiological university space, is respected. It encompasses such values as (1) complementarity of research and education, (2) autonomy, (3) freedom, (4) truth, (5) tolerance, (6) sense of community. In the author's view, modern universities seem to neglect the formative mission. It ought to be remembered, however, how important it is for universities to shape future elites which would participate actively in the creation of free, democratic, non-prejudiced and creative society. 